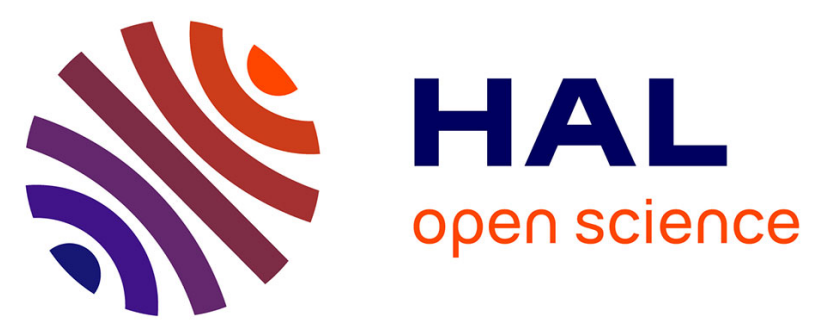

\title{
Hepatotoxicity risk factors and acetaminophen dose adjustment, do prescribers give this issue adequate consideration? A French university hospital study
}

Astrid Bacle, Charlotte Pronier, Helene Gilardi, Elisabeth Polard, Sophie Potin, Lucie-Marie Scailteux

\section{To cite this version:}

Astrid Bacle, Charlotte Pronier, Helene Gilardi, Elisabeth Polard, Sophie Potin, et al.. Hepatotoxicity risk factors and acetaminophen dose adjustment, do prescribers give this issue adequate consideration? A French university hospital study. European Journal of Clinical Pharmacology, 2019, 75 (8), pp.11431151. 10.1007/s00228-019-02674-5 . hal-02119177v2

\section{HAL Id: hal-02119177}

https://hal-univ-rennes1.archives-ouvertes.fr/hal-02119177v2

Submitted on 8 Jul 2019

HAL is a multi-disciplinary open access archive for the deposit and dissemination of scientific research documents, whether they are published or not. The documents may come from teaching and research institutions in France or abroad, or from public or private research centers.
L'archive ouverte pluridisciplinaire HAL, est destinée au dépôt et à la diffusion de documents scientifiques de niveau recherche, publiés ou non, émanant des établissements d'enseignement et de recherche français ou étrangers, des laboratoires publics ou privés. 
1 Hepatotoxicity risk factors and acetaminophen dose adjustment, do 2 prescribers give this issue adequate consideration? a French university 3 hospital study.

4

$5 \quad$ Running title: Hepatic risk factors and acetaminophen dose.

6

7 Astrid BACLE ${ }^{1,2}$, Charlotte PRONIER ${ }^{2,3}$, Hélène GILARDI ${ }^{1}$, Elisabeth POLARD ${ }^{4,5}$, Sophie 8 POTIN $^{1,2}$, Lucie-Marie SCAILTEUX ${ }^{4,5}$.

9

1. Pharmacy Department, CHU Rennes, France

2. Univ Rennes, Inserm, EHESP, Irset (Institut de recherche en santé, environnement et travail) UMR_S 1085 , F-35000 Rennes, France

13 3. Virology Department, CHU Pontchaillou, Rennes, France

14 4. Pharmacovigilance and pharmacoepidemiology centre, Pharmacology Department, CHU Rennes, 15 France

16 5. Univ Rennes, REPERES ([Pharmacoepidemiology and Heath Services Research]) - EA 7449, F1735000 Rennes, France

19 Corresponding author: Lucie-Marie SCAILTEUX

20 Pharmacovigilance and pharmacoepidemiology centre, CHU Rennes

212 , rue Henri Le Guilloux - 35000 Rennes - France

22 Luciemarie.scailteux@chu-rennes.fr

Word count: 3516 words 
Revised manuscript

Abstract $(247 / 250$ words)

Background: The hepatotoxicity of acetaminophen is recognized worldwide. Unfavourable prognoses relating to overdose include liver transplantation and/or death. Several hepatotoxicity risk factors (HRFs) should motivate the adjustment of acetaminophen daily intake (to $<4 \mathrm{~g} /$ day): advanced age, weight $<50 \mathrm{~kg}$, malnutrition, chronic alcoholism, chronic hepatitis B and C and HIV infection, severe chronic renal failure, and hepatocellular insufficiency.

34 Method: Over a seven-day period in Rennes University Hospital in December 2017, using DxCare ${ }^{\circledR}$ 35 software, with an odds ratio estimation, we analysed all acetaminophen prescriptions, to assess to what extent the presence of HRFs altered the prescribers' choice of acetaminophen dose $(<4 \mathrm{~g} /$ day versus $4 \mathrm{~g} /$ day).

Results: Among 1842 patients, considering only the first acetaminophen prescription, $73.7 \%$ were on $4 \mathrm{~g} /$ day. Almost half this population had at least $1 \mathrm{HRF}$. Whereas around $80 \%$ of the prescriptions in the $<4 \mathrm{~g} /$ day group were for patients with at least $1 \mathrm{HFR}$, only $53 \%$ of the prescriptions in the $4 \mathrm{~g} /$ day group concerned patients without HFRs $(p<0.001)$. Age $>75$ and low weight were associated with the prescriber's choice of dose. Neither chronic alcoholism nor hepatocellular insufficiency influenced the acetaminophen doses prescribed.

Conclusion: Considering the widespread use of acetaminophen and its favourable safety profile compared to other analgesic drugs, it appears urgent to remind prescribers of the maximum daily dose recommendations for acetaminophen for patients with HRFs, especially those with chronic alcoholism and hepatocellular insufficiency. 
What is already known about this subject:

63

- Acetaminophen is widely known to be a hepatotoxic drug.

- Recommendations include a maximum daily dose of acetaminophen of $<4 \mathrm{~g} /$ day for patients with hepatotoxicity risk factors (chronic alcoholism, hepatocellular insufficiency, advanced age, anorexia...).

- Studies have described up to $21 \%$ of acetaminophen prescriptions without dose adjustment among patients with hepatotoxicity risk factors.

\section{What this study adds:}

- Age $>75$ and weight $<50 \mathrm{~kg}$ are linked to prescriptions of $<4 \mathrm{~g} /$ day.

- Chronic alcoholism, hepatocellular insufficiency, severe chronic renal failure, chronic viral infections and malnutrition have no influence on the choice of the dose.

- Clinicians should systematically assess patient history, checking for any hepatotoxicity risk factors when prescribing acetaminophen. 


\section{Introduction}

Acetaminophen, also known as "paracetamol", is the most widely prescribed first-line analgesic worldwide. Available as an over-the-counter drug in many countries such as France or the United States, it appears as the most frequent medication involved in both intentional and unintentional drug poisoning, according to the annual report by the American Association of Poison Control Center Data System and the French Addiction Monitoring Network[1, 2].

In case of acetaminophen accumulation and overdose, the main expected adverse effect is acute liver failure, including fulminant hepatitis, which can lead to liver transplantation and/or death[1, 35]. The hepatotoxicity mechanism involves a CYP 450 (mainly 2E1) highly reactive converted metabolite, namely $\mathrm{N}$-acetyl p-benzoquinone imine (NAPQI). NAPQI is physiologically broken down by gluthatione in the liver and excreted in the urine. However, in case of acetaminophen overdose, NAPQI production increases and exceeds the conjugation abilities of glutathione; as it binds to the hepatocellular membrane proteins, it induces liver parenchymal cell death[6].

For a mean adult weight, clinical symptomatic acetaminophen hepatotoxicity is usually expected after a single acetaminophen ingestion of around 10 grams per 24 hours or $150 \mathrm{mg} / \mathrm{kg}$, with an initial phase of cytolysis occurring in the first 24 to 48 hours. The hepatotoxicity is dose-dependent and can be predicted by a nomogram[7]. Immediately after an acetaminophen overdose, $\mathrm{N}$-acetylcysteine is used to restore glutathione reserves which can limit hepatotoxicity[8] with recovery expected in 4-5 days where the prognosis is favourable[9]. Studies have shown that advanced age, chronic alcohol consumption, as well as fasting/anorexia and poor nutritional status could be associated with gluthatione depletion; it is worth noting that chronic alcohol consumption has also been shown to be a CYP 2E1 inducer leading to NAPQI increase[10-12]. Chronic renal failure as well as chronic liver disease (hepatic failure, cirrhosis, viral hepatitis) are also considered to be acetaminophen hepatotoxicity risk factors (HRFs)[13-16] and should lead to an adjustment of acetaminophen daily intake. Meanwhile, case reports of hepatitis observed at therapeutic doses of 3 or $4 \mathrm{~g} /$ day have been reported among patients with low weight, a history of chronic alcoholism, hepatic steatosis or recent fasting[17-21]. Furthermore, certain randomised controlled trials have reported an increase (mostly 3 to 4 times the normal upper limit) in serum alanine aminotransferase activity (ALT) for a significant proportion of 'healthy' patients exposed to acetaminophen at $4 \mathrm{~g} /$ day for several days, compared to placebo[22, 23], although the clinical significance is uncertain.

Recommendations have been established for acetaminophen prescription, with a maximum daily dose of 4 grams, and they include dose adjustment for patients with HRFs[24-26]. Dose adjustments are detailed in most summary of product characteristics (SmPC) for acetaminophen-based 
medications. A lack of accurate and harmonised information across SmPC is however observed. In general terms, it is recommended to use the "lowest possible dose" for symptom relief and make gradual adaptation of the dose to the pain. Regarding the maximum acetaminophen dose, some

100 SmPC mention that "it is generally not necessary to exceed 3 g per 24 hours". Regarding dose 101 adjustments for special populations (liver failure, renal failure, dehydration, weight $<50 \mathrm{~kg} . .$. ),

102 although it is formulated differently across SmPC, it is recommended to use the lowest possible effective doses, and specifically to increase interval between two intakes (>8h) in severe chronic renal failure. The maximum recommended doses in special population are given as an indication (sometimes $2 \mathrm{~g} /$ day or $3 \mathrm{~g} /$ day) but are not necessarily related to clinical studies (no reference provided in SmPC)."

107 Few studies have described acetaminophen prescription patterns in hospitals or assessed

108 compliance with recommendations relating to HRFs: in French and American cohorts, failure to 109 adjust doses in view of the presence of HRFs was observed in $1 \%$ to $21 \%$ of prescriptions[27-31]. It 110 can be noted that neither the type of hospital units (surgery, geriatrics...) nor pharmaceutical 111 validation studies have an influence on dose adjustment[27, 30].

112 This work was performed after the notification in our local Pharmacovigilance unit of cases of 113 acetaminophen toxicity at doses in the therapeutic range among patients with HRFs: the most 114 recent, with a fatal outcome, concerned a 72-year-old hospitalised man who developed cytolysis 115 with acute hepatic failure two days after the initiation of $4 \mathrm{~g} /$ day acetaminophen for acute pain. The 116 patient's history included alcoholism and cachexia, in a context of hepatic steatosis, septic shock and 117 the discovery of metastatic colorectal cancer.

118 As we believe that some HRFs are more likely to induce dose adjustments than others, the aim of our 119 study was to assess to what extent the existence of HRFs (single or in combination) modify the 120 prescribers' choice of acetaminophen dose ( $<4 \mathrm{~g} /$ day versus $4 \mathrm{~g} /$ day). 
Revised manuscript

122

123 We conducted a retrospective monocentric cross-sectional study including all patients with an

124 acetaminophen prescription in Rennes University Hospital.

125 All data was collected in accordance with the French legislation on retrospective clinical studies, in 126 accordance with the precepts established by the Helsinki declaration.

127

The extraction of data concerning acetaminophen prescriptions (oral and intravenous) (Dxcare ${ }^{\circledR}$ software version 7.5.20p049, Medasys ${ }^{\circledR}$ ) was carried out over one week, from the $13^{\text {th }}$ to the $19^{\text {th }}$ December 2017. Only patients aged over 18 years, i.e. born after 12/12/1999, were considered for

133

134

All medications containing acetaminophen were considered, precribed on their own or in combination with other drugs. We collected the names of the medications, the routes of administration and the daily doses. Patients were categorised as having a maximum dose of $4 \mathrm{~g} /$ day or less than $4 \mathrm{~g} /$ day. The patients for whom the dose was specified as " $1 \mathrm{~g}$ 'upon request', maximum 4 times a day," were considered as having the maximum $4 \mathrm{~g} /$ day dose.

140

\section{- Other variables}

142 Data was collected from the patients' electronic files: age at the time of the acetaminophen 143 prescription, gender, hospital unit, weight, body mass index, biological parameter values (serum 144 creatinine, serum alanine aminotransferase (ALT), aspartate aminotransferase (AST), alkaline 145 phosphatase (PAL), gamma-glutamyl transpeptidase (GGT), direct bilirubin, total bilirubin, 146 prothrombin time (TP), international normalised ratio (INR), factor $\mathrm{V}$, serum albumin and pre147 albumin), the presence of chronic viral hepatitis (B or C) and human immunodeficiency virus (HIV), 148 current chronic alcoholism, current intake of oral anticoagulants, current malnutrition, history of liver 149 or renal transplantation. 
153 According to the SmPC and French recommendations on acetaminophen prescription [24-26], we

154 considered seven HRF categories that should lead to dose adjustment, defined as followed:

155 Descriptive statistics characterised patients at the time of the $1^{\text {st }}$ acetaminophen prescription.

- $\quad$ age over 75 years, i.e. patients born before the $12^{\text {th }}$ December 1942;

- low weight: under $50 \mathrm{~kg}$;

- malnutrition defined by the presence of one or more of the following criteria: serum albumin $<30 \mathrm{~g} / \mathrm{L}$, serum pre-albumin $<150 \mathrm{mg} / \mathrm{L}, \mathrm{BMI}<18.5$ for patients $<70$ years old, $\mathrm{BMI}<21$ for patients $\geq 70$ years old, the specific mention of "malnutrition" in the electronic file;

- chronic alcoholism: we selected patients whose electronic file records specified excessive and chronic alcohol consumption;

- current chronic viral infections (hepatitis B, C and/or D) and/or HIV; patient status was individually checked by a virologist (CP author). HIV patients with an undetectable viral load were considered as presenting a risk factor; patients who had recovered from hepatitis $C$ at study entry were not considered as presenting a risk factor;

- severe chronic renal failure defined by a creatinine clearance value (estimated by the CKDEPI equation) of $<30 \mathrm{ml} / \mathrm{min}$ in the electronic file;

- hepatocellular insufficiency, biologically defined by one or more following abnormalities: factor $\mathrm{V}<70 \%$, prothrombin time decrease, INR $>1.5$ for patients without anticoagulant treatment or INR $>5$ with anticoagulant treatment, ALT > $40 \mathrm{UI} / \mathrm{L}, \mathrm{AST}>40 \mathrm{UI} / \mathrm{L}$. Other biological parameters were considered only in case of association with other abnormalities: serum albumin concentration $<35 \mathrm{~g} / \mathrm{L}$ and/or the following clinical signs specified in the electronic file: "jaundice", "hepatic encephalopathy", "cirrhosis", "stellate angioma" or "palmar erythrosis", "alcoholic hepatitis", "viral hepatitis".

\section{- Statistical methods}

In case of several acetaminophen prescriptions for the same patient, only the first was considered for the descriptive and statistical analyses in order to ensure the independence of the data and analyses. We considered the first prescription as the initial prescriber's intention to treat, as the second or following prescriptions could be related to medical or pharmaceutical re-assessment.

Proportions were compared across levels of exposure using chi-square tests or Fisher's exact test; age was compared using the Student $t$ test. 
Revised manuscript

184 A logistic regression model considering all HRFs was used to estimate those that were significantly 185 related to the prescribers' choice of acetaminophen dose ( $<4 \mathrm{~g} /$ day versus $4 \mathrm{~g} /$ day).

186 A descending step-by-step selection model was used, retaining only the variables (HRF) significantly

187 associated with acetaminophen dose adjustment $(<4 \mathrm{~g} /$ day $)$ at a $5 \%$ statistical threshold.

188 An odds ratio estimation was used to determine which HRFs were associated with dose adjustment 189 (< $4 \mathrm{~g} /$ day or $4 \mathrm{~g} /$ day $)$ in the prescribers' prescriptions.

190 All analyses were conducted using the SAS statistical package (version 9.4; SAS Institute, Cary, NC, 191 USA). 
Revised manuscript

192

193

194

195

196

197

198

199

200

201

202

203

204

205

206

207

208

209

210

211

212

213

214

215

216

217 (data not shown).

218 It can be noted that among patients $>75$ years $(n=606)$, who accounted for one-third of the overall 219 population, all had $1(n=315)$ or $2(n=291)$ HRFs. Despite this, around $50 \%(n=302)$ had no dose 220 adjustment.

221 As regards the administration route, 63 (3,4 \%) concerned intravenous use, most of whom (86 \%; 222

\section{Results}

Over a seven-day period in December 2017, 2338 acetaminophen prescriptions were collected from Rennes University Hospital. After excluding prescriptions for patients under 18 years, 2048 acetaminophen prescriptions concerning 1842 patients were included in this study. Retaining only the first prescription for each patient, 1842 prescriptions were used for the analyses (see Figure 1).

The characteristics of the study population are displayed in table 1 . Around $54 \%$ were female. The median age was 65 years (min 18 years - max 101 years) and $32.9 \%$ were over 75 years old.

Among the 1842 prescriptions, $73.7 \%$ were for $4 \mathrm{~g} /$ day (table 1 ); it can be noted that no prescription exceeded the maximum 4-g daily dose. Females were more frequently in the $<4 \mathrm{~g} /$ day group than in the $4 \mathrm{~g}$ /day group ( $60.1 \%$ vs $51.3 \%, \mathrm{p}<0.001$ ). Regarding the hospital unit, in the $<4 \mathrm{~g} /$ day group, prescribers mainly belonged to geriatric or other clinical units (respectively $44.6 \%$ and $41.1 \%$ ); in the $4 \mathrm{~g} /$ day group, prescriptions mainly derived from surgery / anaesthesia / intensive care / palliative units and other clinical units (respectively $57.1 \%$ and $32.6 \%$ ).

Around $55 \%$ of the overall population presented with at least one HRF. Among patients with only one HRF ( $n=549)$, the HRF was mainly age $>75$ years, and secondarily hepatocellular insufficiency or chronic alcoholism (appendix table 1). Whereas around $80 \%$ of prescriptions in the $<4 \mathrm{~g} /$ day group were for patients with at least $1 \mathrm{HFR}$, only $53 \%$ of prescriptions in the $4 \mathrm{~g} /$ day group concerned patients without any HFR $(p<0.001)$. Furthermore, some HRFs were significantly more frequent in the $<4 \mathrm{~g} /$ day group (table 1 ) : age $>75$, low weight, malnutrition and severe renal failure.

Concerning the statistical analysis, only prescriptions without missing data on the HRF category were used ( $n=1103$ ), including 363 patients in the $<4 \mathrm{~g} /$ day group and 740 in the $4 \mathrm{~g} /$ day group. The logistic regression showed that age $>75$ and low weight were significantly associated with the prescriber's choice of dose (table 2). The descending step-by-step model confirmed that only age > 75 and low weight remained significantly associated with the $<4 \mathrm{~g} /$ day dose (data not shown). We observed similar results in a sensitivity analysis using age $>75$ and weight as continuous variables $\mathrm{n}=54$ ) had a $4 \mathrm{~g} /$ day dose. In those patients, at least one HRF was recorded in 34 patients. As regards the 9 patients in the $<4$ g/day group, 1 had no HRF, 2 had only one HRF (age $>75$ in both cases) and 
Revised manuscript

2247 had at least 2 HRF. More in depth, Paracetamol B Braun $1 \mathrm{~g} / 100 \mathrm{ml}^{\circledR}$ (adult formulation) was used in 225 all cases. Its SmPC recommends a dose adjustment considering weight category (between 33 and 50 $226 \mathrm{~kg}$ or $>50 \mathrm{~kg}$ ) and whether HRF are present (chronic alcoholism, hepatocellular insufficiency, chronic 227 malnutrition, and dehydration for which maximal dose is $3 \mathrm{~g} /$ day). 


\section{Discussion}

231 In our seven-day study focusing on acetaminophen prescriptions in Rennes University Hospital, 232 around three quarters of prescriptions were full-dose (4 g/day); in this group, $47 \%$ of prescriptions 233 were for patients with at least one HRF: these can be considered as non-compliant prescriptions, and 234 the proportion is greater than in previous studies showing up to $21 \%$ of non-compliant 235 acetaminophen prescriptions in hospital[27-31]. The lower non-compliant prescriptions could be 236 related to the fact that age $>75$ years is not considered as a HRF in SmPC and no dose adjustment is recommended. As mentioned by Pacé et al., medicine and geriatric units seem to be more aware of the HRFs of acetaminophen[31]: in our study the number of prescriptions for $<4 \mathrm{~g} /$ day in these units amounted to around $85 \%$ of the prescriptions.

240 For the HRFs studied, we showed that age $>75$ years and low weight influenced the prescribers' 241 choice of dose. The impact of advanced age here could be linked to age in our cohort since the 242 median age was 65.0 years and one third of the patients were over 75 years old. Another explanation 243 linked to age is the fact that, in Rennes University Hospital, prescribers are particularly aware of 244 dosage adjustment for elderly patients thanks to careful monitoring by the pharmacists. Surprisingly, 245 neither chronic alcoholism nor hepatocellular insufficiency were associated with dose adjustment. 246 Although acetaminophen is a highly hepatotoxic drug and its metabolism involves the liver, 247 prescribers appear not to consider these HRFs in their choice of dose. Hepatic tests after 248 acetaminophen initiation were not performed in our study, so we could not check for clinical or 249 biological signs of hepatotoxicity among patients with these HRFs. Pace et al. also observed a high 250 rate of non-compliance with recommendations (> $68 \%$ ) for patients with chronic alcoholism or 251 hepatocellular insufficiency[31], suggesting that prescribers need to be made aware of dose 252 adjustments in these patient groups. Unlike our study where low weight was a dose-adjustment 253 variable in acetaminophen prescriptions by clinicians, this factor was explored in heterogeneous 254 manner in other studies and was related to non-compliance[29, 31].

255 None of the prescriptions exceeded the 4-g per day, which is no doubt linked to the use of software 256 (DxCare ${ }^{\circledR}$ ) limiting acetaminophen daily doses; a warning is also displayed when several drugs 257 containing acetaminophen are coprescribed.

258 Some HRF as well as their definition can be discussed. In a literature review, Caparrotta et al. found 259 no good quality evidence to establish that factors were HRF[11]. They notably pointed that the safe 260 oral acetaminophen dose in patients $<50 \mathrm{~kg}$ had not been established. In our study, chronic 261 alcoholism status has only been identified through a subjective HRF reading (potentially 262 underestimated) without re-assessment by an independent committee. No additional information 
263 was collected (severity, care...). Age, especially advanced age is described as HRF whereas literature 264 data are inconsistent (PK, case series, population-based studies)[11, 12]. As evoked by Caparrotta et 265 al. there is a lack of good quality clinical evidence that older people have a clinically significant 266 difference in acetaminophen metabolism or are at increased risk of toxicity at (supra)therapeutic 267 dose. Age cut-off also varied across studies[12, 32-34]. Moreover, neither French SmPC nor recommendations provide an age cut-off. Considering that "old age" definition is complex, potentially subjective (physical, psychological conditions), and is not only related to years, we arbitrarily chose 75 years-old as cut-off in our study. In addition to biological criteria, hepatocellular insufficiency definition also included a HRF reading seeking specific terms (cirrhosis, hepatic encephalopathy) without secondary objective re-assessment. All these limitations could have induced misclassification bias of HRF.

274 The main strength of our work lies in the data collection that took place within a week and involved 275 all adult patients' electronic files in all Rennes University Hospital units. Among the weaknesses, we 276 recognize that our results concern only one hospital and may not be representative of French 277 hospital prescribers. But the objective of our study was not to compare with practices in other 278 hospitals but rather to highlight the fact that HRFs are not always considered by prescribers, even in 279 university hospitals, when prescribing acetaminophen. Nor did we consider the indication for 280 acetaminophen, treatment duration or the potential need for opioid treatments, which could have 281 impacted dose adjustment. Considering a safety approach, we deliberately focused our study on the 282 first acetaminophen dose prescribed, irrespective of its indication, as representing intention-to-treat. 283 Furthermore, our statistical analysis did not include all the 1842 prescriptions in the overall 284 population as a result of missing data for some HRFs: around $33 \%$ of patients had missing data for 285 the hepatocellular insufficiency variable, and $10 \%$ for malnutrition status. It can be noted that some 286 HRFs could have been under-estimated, especially alcoholism which is often concealed by patients when questioned on the subject. We did not assess either whether the $4 \mathrm{~g} /$ day dose for patients with one or more HRF had clinical significance for liver function, nor did we consider the type of HRF; indeed, hepatic cytolysis is more likely among patients with cirrhosis than among elderly patients 290 without other liver diseases. We did not consider co-medication and especially drug-drug interaction, 291 nor other clinical conditions (sepsis, heart failure[35, 36]) that affect the hepatic enzymes. In 292 acetaminophen SmPCs, drug interaction section mentioned a precaution of use when associated with 293 other hepatotoxic drugs or CYP 450 drug enzyme inducers. However, on the basis of the French drug294 drug interaction referential provided by the French Health Authorities (French National Agency for 295 Medicines and Health Products Safety [ANSM])[37], no clinically significant interaction with 296 paracetamol was highlighted, even with drugs impacting CYP 2E1 (doxycycline, isoniazide). 
We should bear in mind that although acetaminophen is the most widely recognized drug in inducing liver damage[38, 39], its use is commonplace, mainly as a result of a good reputation with regard to safety compared to other analgesic drugs (non-steroid anti-inflammatory drugs for example). In

300 order to limit the risk of poisoning and suicide using acetaminophen, France was the first country in 301 Europe in the 1980 s to limit packaging to a maximum dose of 8 grams of acetaminophen. In the 2000s, the Federal Drug Agency in the United States and the United Kingdom Health Authorities also restricted the acetaminophen pack size[40, 41]; the FDA also limited the acetaminophen dosage unit to $325 \mathrm{mg}$ in 2011[42, 43]. Despite this, acetaminophen remains the first drug involved in overdose (intentional or otherwise)[1, 2]. In 2017, W. Lee described the controversy surrounding acetaminophen use in pain management[9]: he pointed out that worldwide regulatory efforts had been ineffective in reducing the cost in money and lives resulting from its hepatotoxicity. In France,

308 however, the French Pharmacovigilance network regularly collects case reports of acute 309 acetaminophen poisoning. A recent fatal case in December 2017, which was highly publicized across 310 France, led the Health Authorities to reinforce the data available on acetaminophen-based drugs: the 311 objective was to raise awareness among patients and prescribers about liver damage. A public 312 consultation was thus initiated on August $20^{\text {th }}, 2018$, ending on September $30^{\text {th }}, 2018$ for the 313 definition of the best warning message to put on drug packaging[44]; but the results have not yet 314 been issued. With the exception of hepatocellular insufficiency, there is a lack of information on dose 315 adjustment, special warnings or contraindications in case of other HRFs with some acetaminophenbased medications (e.g. Paracetamol Teva 1g, tablets; Paracetamol EG 500 mg/30 mg ${ }^{\circledR}$, effervescent scored tablets; Paracetamol Zydus $500 \mathrm{mg}$, gelules $\left.{ }^{\circledR} . . .[45-47]\right)$. It is worth noting that maximum dose could vary from one SmPC to another: for instance, in case of HRF, $2 \mathrm{~g} /$ day is mentioned in Paracetamol AHCL 1g, effervescent tablet[48] compared to 3g/day in Doliprane $1 \mathrm{~g}$, tablets[49]. In general terms, lack of SmPC harmonisation, especially regarding the appropriate maximal dose to be used in case of HRF is a limitation for clinicians' prescriptions compliance. ANSM planned a

322 harmonisation of the warnings included in the SmPC for acetaminophen-based drugs in 2019.

324 with (sub)therapeutic $\leqslant 4 \mathrm{~g} /$ day dose and the results of the current study, in Rennes University 325 Hospital, several improvement measures are planned: awareness raising at the residents' welcome 326 seminars twice a year, poster campaign in clinical departments, configuration of software as regards 327 prescription schemes, awareness raising of pharmacist responsible of prescriptions' pharmaceutical 328 validation. 
Revised manuscript

\section{Conclusion}

331 This work shows that in Rennes University Hospital, HRFs are not systematically considered by 332 clinicians when acetaminophen is prescribed. Age $>75$ years and low weight had a greater impact on 333 acetaminophen prescription than alcoholism, malnutrition, chronic viral hepatitis, severe renal 334 failure or hepatocellular insufficiency. Considering the widespread use of acetaminophen, it appears 335 important to remind healthcare professionals and patients of the hepatotoxicity risk resulting from 336 misuse, especially in presence of HRF. 
1. Gummin DD, Mowry JB, Spyker DA, et al (2017) 2016 Annual Report of the American Association of Poison Control Centers' National Poison Data System (NPDS): 34th Annual Report. Clin Toxicol (Phila) 55:1072-1252. https://doi.org/10.1080/15563650.2017.1388087

343 2. (2018) Abstracts of the Annual Meeting of French Society of Pharmacology and Therapeutics, and INSERM Clinical Research Centers (CIC) Meeting, 12-14 June 2018, Toulouse, France. "Misuse of analgesics in the context of self-medication: resutls of a large cross-sectional survey from the DANTE study (une Décennie d'ANTalgiques en France) (CO-041)" by Guerlais M. et al. Fundam Clin Pharmacol 32:16. https://doi.org/10.1111/fcp.12370

3. Bernal W, Auzinger G, Dhawan A, Wendon J (2010) Acute liver failure. The Lancet 376:190-201

4. Hawton K, Bergen $\mathrm{H}$, Simkin S, et al (2013) Long term effect of reduced pack sizes of paracetamol on poisoning deaths and liver transplant activity in England and Wales: interrupted time series analyses. BMJ 346:f403

5. Gulmez SE, Larrey D, Pageaux G-P, et al (2015) Liver transplant associated with paracetamol overdose: results from the seven-country SALT study. Br J Clin Pharmacol 80:599-606

352 6. Vale JA, Proudfoot AT (1995) Paracetamol (acetaminophen) poisoning. Lancet 346:547-552

353 7. Bateman DN (2015) Paracetamol poisoning: beyond the nomogram. Br J Clin Pharmacol 80:45-50

354 8. Rumack BH, Bateman DN (2012) Acetaminophen and acetylcysteine dose and duration: past, present and future.

355 Clin Toxicol (Phila) 50:91-98

356 9. Lee WM (2017) Acetaminophen (APAP) hepatotoxicity-Isn't it time for APAP to go away? J Hepatol 67:1324-1331

357 10. Twycross R, Pace V, Mihalyo M, Wilcock A (2013) Acetaminophen (paracetamol). J Pain Symptom Manage 46:747-

$358 \quad 755$

359 11. Caparrotta TM, Antoine DJ, Dear JW (2018) Are some people at increased risk of paracetamol-induced liver injury?

360 A critical review of the literature. Eur J Clin Pharmacol 74:147-160

361 12. (2018) What dose of paracetamol for older people? Drug Ther Bull 56:69-72.

362 https://doi.org/10.1136/dtb.2018.6.0636

363 13. Schena FP (2011) Management of patients with chronic kidney disease. Intern Emerg Med 6 Suppl 1:77-83

364 14. Blantz RC (1996) Acetaminophen: acute and chronic effects on renal function. Am J Kidney Dis 28:S3-6

$36515 . \quad$ Larrey D (2006) [Is there a risk to prescribe paracetamol at therapeutic doses in patients with acute or chronic

366 liver disease?]. Gastroenterol Clin Biol 30:753-755

367 16. Bunchorntavakul C, Reddy KR (2013) Acetaminophen-related hepatotoxicity. Clin Liver Dis 17:587-607, viii

368 17. Kurtovic J, Riordan SM (2003) Paracetamol-induced hepatotoxicity at recommended dosage. J Intern Med

$369253: 240-243$

370 18. Eriksson LS, Broomé U, Kalin M, Lindholm M (1992) Hepatotoxicity due to repeated intake of low doses of 371 paracetamol. J Intern Med 231:567-570

372 19. Krähenbuhl S, Brauchli Y, Kummer O, et al (2007) Acute liver failure in two patients with regular alcohol

373 consumption ingesting paracetamol at therapeutic dosage. Digestion 75:232-237

374 20. Forget P, Wittebole X, Laterre P-F (2009) Therapeutic dose of acetaminophen may induce fulminant hepatitis in

375 the presence of risk factors: a report of two cases. Br J Anaesth 103:899-900

376 21. Claridge LC, Eksteen B, Smith A, et al (2010) Acute liver failure after administration of paracetamol at the

377 maximum recommended daily dose in adults. BMJ 341:c6764

378 22. Watkins PB, Kaplowitz N, Slattery JT, et al (2006) Aminotransferase elevations in healthy adults receiving 4 grams

379 of acetaminophen daily: a randomized controlled trial. JAMA 296:87-93

$38023 . \quad H e a r d ~ K$, Green JL, Anderson V, et al (2014) A randomized, placebo-controlled trial to determine the course of

381 aminotransferase elevation during prolonged acetaminophen administration. BMC Pharmacol Toxicol 15:39

382 24. Agence Nationale d'Accréditation et d'Évaluation en Santé (ANAES) (2000) Evaluation et prise en charge

383 thérapeutique de la douleur chez les personnes âgées ayant des troubles de la communication verbale -

$38425 . \quad$ Haute Autorité de Santé (2007) Surveillance des malades atteints de cirrhose non compliquée et prévention

385 primaire des complications - Recommandations

386 26. Agence française de sécurité sanitaire des produits de santé (AFSSAPS) (2011) Prise en charge des douleurs de

387 l'adulte modérées à intenses. Recommandations après le retrait des associations dextropropoxyphène/paracétamol et

388 dextropropoxyphène/paracétamol/caféine.

389 27. Arques-Armoiry E, Cabelguenne D, Stamm C, et al (2010) [Most frequent drug-related events detected by

390 pharmacists during prescription analysis in a university hospital]. Rev Med Interne 31:804-811

391 28. Zhou L, Maviglia SM, Mahoney LM, et al (2012) Supratherapeutic dosing of acetaminophen among hospitalized

392 patients. Arch Intern Med 172:1721-1728

393 29. Charpiat B, Henry A, Leboucher G, et al (2012) Overdosed prescription of paracetamol (acetaminophen) in a

394 teaching hospital. Ann Pharm Fr 70:213-218

$39530 . \quad$ Viguier F, Roessle C, Zerhouni L, et al (2016) [Clinical pharmacist influence at hospital to prevent overdosed

396 prescription of acetaminophen]. Ann Pharm Fr 74:482-488

397 31. Pace J-B, Nave V, Moulis M, et al (2017) [Prescription of acetaminophen in five French hospitals: What are the

398 practices?]. Therapie 72:579-586

$39932 . \quad$ Wynne HA, Cope LH, Herd B, et al (1990) The association of age and frailty with paracetamol conjugation in man. 
$40133 . \quad$ Mitchell SJ, Hilmer SN, Murnion BP, Matthews S (2011) Hepatotoxicity of therapeutic short-course paracetamol in

402 hospital inpatients: impact of ageing and frailty. J Clin Pharm Ther 36:327-335

403 34. Liukas A, Kuusniemi K, Aantaa R, et al (2011) Pharmacokinetics of intravenous paracetamol in elderly patients. Clin 404 Pharmacokinet 50:121-129

405 35. Yan J, Li S, Li S (2014) The role of the liver in sepsis. Int Rev Immunol 33:498-510

406 36. Koehne de Gonzalez AK, Lefkowitch JH (2017) Heart Disease and the Liver: Pathologic Evaluation. Gastroenterol

407 Clin North Am 46:421-435

$408 \quad 37$. Agence Nationale de Sécurité du Médicament et des Produits de Santé (ANSM) (2018) Thésaurus des interactions 409 médicamenteuses - mise à jour mars 2018

$410 \quad 38 . \quad$ Leise MD, Poterucha JJ, Talwalkar JA (2014) Drug-induced liver injury. Mayo Clin Proc 89:95-106

411 39. Fisher K, Vuppalanchi R, Saxena R (2015) Drug-Induced Liver Injury. Arch Pathol Lab Med 139:876-887

412 40. Hawkins LC, Edwards JN, Dargan PI (2007) Impact of restricting paracetamol pack sizes on paracetamol poisoning 413 in the United Kingdom: a review of the literature. Drug Saf 30:465-479

414 41. Krenzelok EP (2009) The FDA Acetaminophen Advisory Committee Meeting - what is the future of acetaminophen 415 in the United States? The perspective of a committee member. Clin Toxicol (Phila) 47:784-789

416 42. Federal Drug Agency (FDA) Prescription Drug Products Containing Acetaminophen: Actions to Reduce Liver Injury 417 from Unintentional Overdose. Notice Document. https://www.regulations.gov/document?D=FDA-2011-N-0021-0001.

418 Accessed 10 Sep 2018

$41943 . \quad$ Federal Drug Agency (FDA) FDA Drug Safety Communication:[1-13-2011] Prescription Acetaminophen Products to 420 be Limited to 325 mg Per Dosage Unit; Boxed Warning Will Highlight Potential for Severe Liver Failure.

421 https://www.fda.gov/Drugs/DrugSafety/ucm239821.htm. Accessed 10 Sep 2018

422 44. Paracétamol : I'ANSM lance une consultation publique pour sensibiliser les patients et les professionnels de santé au risque de toxicité pour le foie en cas de mésusage - Point d'Information - ANSM : Agence nationale de sécurité du médicament et des produits de santé. https://ansm.sante.fr/S-informer/Points-d-information-Points-dinformation/Paracetamol-I-ANSM-lance-une-consultation-publique-pour-sensibiliser-les-patients-et-les-professionnels-desante-au-risque-de-toxicite-pour-le-foie-en-cas-de-mesusage-Point-d-Information. Accessed 10 Sep 2018 45. Résumé des caractéristiques du produit - Paracétamol Teva 1g, comprimé. (page consultée le 10/09/2018). http://agence-prd.ansm.sante.fr/php/ecodex/rcp/R0291484.htm. Accessed 10 Sep 2018

46. Résumé des caractéristiques du produit - Paracétamol Codéine EG $500 \mathrm{mg} / 30 \mathrm{mg}$, comprimé effervescent sécable. (page consultée le 10/09/2018). http://agence-prd.ansm.sante.fr/php/ecodex/rcp/R0286140.htm. Accessed 10 Sep 2018

47. Résumé des caractéristiques du produit - Paracétamol Zydus 500 mg, gélule. (page consultée le 10/09/2018). http://agence-prd.ansm.sante.fr/php/ecodex/frames.php?specid=67445776\&typedoc=R\&ref=R0230023.htm 48. Résumé des caractéristiques du produit - Paracétamol AHCL 1g, comprimé effervescent. (page consultée le 17/01/2019). http://agence-prd.ansm.sante.fr/php/ecodex/frames.php?specid=61754805\&typedoc=R\&ref=R0328124.htm. Accessed 17 Jan 2019

49. Résumé des caractéristiques du produit - Doliprane $100 \mathrm{mg}$, comprimé. (page consultée le 17/01/2019). http://agence-prd.ansm.sante.fr/php/ecodex/frames.php?specid=60234100\&typedoc=R\&ref=R0301400.htm. Accessed 17 Jan 2019 
Revised manuscript

\section{Authors contribution:}

443 LMS and AB had full access to all of the data in the study and take responsibility for the integrity of

444 the data and the accuracy of the data analysis. SP, EP, LMS and AB were part of the study concept 445 and design. All authors were a part in the acquisition, analysis or interpretation of data. Drafting of 446 the manuscript was done by LMS. All authors took part in the critical revision of the manuscript for 447 important intellectual content. LMS was a part in the statistical analysis. Administrative, technical or 448 material support was provided by Rennes Hospital University.

449

450 Conflict of interest:

$451 \quad$ None.

452

453 Funding / support:

454 None.

455

456 Additional contribution:

457 We thank Jean-Paul Sinteff (Medical Information Departement, CHU Rennes) for the DxCare ${ }^{\circledR}$ 458 software data extraction, and Adrien Turban, Anne-Sophie Michel, Justine Geffroy and Stephanie 459 Ollivier for their help in the data collection.

460

461

462

463

464

465

466

467

468

469

470 
Revised manuscript

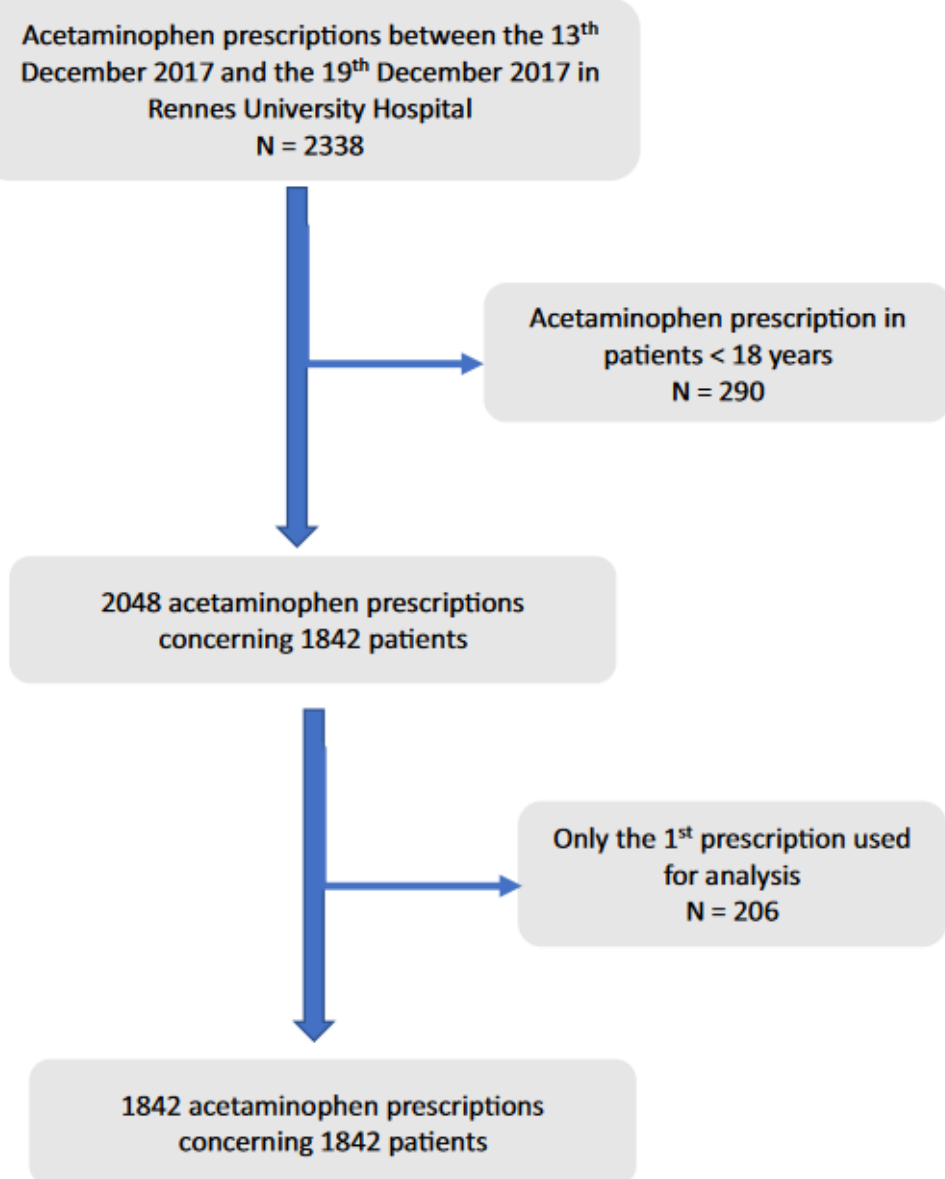

Fig. 1 Flowchart 
Table 1. Population characteristics

\begin{tabular}{|c|c|c|c|c|}
\hline & Overall & $<4 \mathrm{~g} /$ day & $4 \mathrm{~g} /$ day & p-value \\
\hline number of prescription (\%) & $1842(100)$ & $484(26.3)$ & $1358(73.7)$ & \\
\hline $\begin{array}{l}\text { Age in year, mean (SD) } \\
\qquad(\min -\max )\end{array}$ & $\begin{array}{l}61.6(20.8) \\
(18-101)\end{array}$ & $\begin{array}{l}74.8(17.2) \\
(18-97)\end{array}$ & $\begin{array}{l}57.0(20.0) \\
(18-101)\end{array}$ & $<0.001$ \\
\hline Female Sex & $987(53.6)$ & $291(60.1)$ & $696(51.3)$ & $<0.001$ \\
\hline $\begin{array}{l}\text { Weight (kg), mean (SD) } \\
\text { (missing value, } n=166 \text { ) }\end{array}$ & $\begin{array}{c}70.5(17.4) \\
(\min 25.5-\max 164.0)\end{array}$ & $\begin{array}{c}66.2(18.8) \\
(\min 25.5-\max 134.6)\end{array}$ & $\begin{array}{c}72.1(16.6) \\
(\min 34.0-\max 164.0)\end{array}$ & \\
\hline $\begin{array}{c}\text { BMI, mean (SD) } \\
\text { (missing value, } n=1269 \text { ) }\end{array}$ & $\begin{array}{c}25.2(5.6) \\
(\min 12.0-\max 55.8)\end{array}$ & $\begin{array}{c}25.1(6.1) \\
(\min 12.0-\max 55.8)\end{array}$ & $\begin{array}{c}25.3(5.1) \\
(\min 14.7-\max 46.7)\end{array}$ & \\
\hline Hospitalisation Department & & & & $<0.001$ \\
\hline $\begin{array}{l}\text { Surgery, anaesthesia, intensive } \\
\text { care or palliative departments }\end{array}$ & $835(45.3)$ & $59(12.2)$ & $776(57.1)$ & \\
\hline Emergency department & $74(4.0)$ & $10(2.1)$ & $64(4.7)$ & \\
\hline Geriatric department & $291(15.8)$ & $216(44.6)$ & $75(5.5)$ & \\
\hline Other clinical departments & $642(34.9)$ & $199(41.1)$ & $443(32.6)$ & \\
\hline$\frac{\text { Number of hepatotoxicty risk }}{\text { factor }}$ & & & & $<0.001$ \\
\hline 0 & $819(44.5)$ & $99(20.5)$ & $720(53.0)$ & \\
\hline 1 & $549(29.8)$ & $173(35.7)$ & $376(27.7)$ & \\
\hline$\geq 2$ & $474(25.7)$ & $212(43.8)$ & $262(19.3)$ & \\
\hline \multicolumn{5}{|l|}{$\begin{array}{l}\text { Description by type of } \\
\text { hepatotoxicity risk factor }\end{array}$} \\
\hline age $>75$ & $606(32.9)$ & $304(62.8)$ & $302(22.2)$ & $<0.001$ \\
\hline $\begin{array}{l}\text { low weight } \\
\text { (missing value, } n=168 \text { ) }\end{array}$ & $171(9.3)$ & $93(20.5)$ & $78(6.4)$ & $<0.001$ \\
\hline $\begin{array}{c}\text { malnutrition } \\
\text { (missing value, } n=207 \text { ) }\end{array}$ & $363(22.2)$ & $138(31.3)$ & $225(18.8)$ & $<0.001$ \\
\hline chronic alcoholism & $157(8.5)$ & $43(8.9)$ & $114(8.4)$ & 0.74 \\
\hline chronic viral hepatitis & $53(2.9)$ & $15(3.1)$ & $38(2.8)$ & 0.73 \\
\hline $\begin{array}{l}\text { chronic severe renal failure } \\
\text { (missing value, } n=413 \text { ) }\end{array}$ & $113(7.9)$ & $48(10.6)$ & $65(6.7)$ & 0.01 \\
\hline $\begin{array}{l}\text { hepatocellular insufficiency } \\
\text { (missing value, } n=501 \text { ) }\end{array}$ & $272(20.3)$ & $74(18.1)$ & $198(21.2)$ & 0.19 \\
\hline
\end{tabular}


Appendix Table 1. Repartition of patients with only one hepatotoxicity risk factor $(\mathrm{n}=549)$ by type of risk factor.

\begin{tabular}{|c|c|c|}
\hline Hepatotoxicity risk factor (HRF) & $\mathbf{n}$ & \% \\
\hline Age > 75 & 315 & 57.4 \\
\hline Low weight & 21 & 3.8 \\
\hline Malnutrition & 47 & 8.6 \\
\hline Chronic alcoholism & 55 & 10.0 \\
\hline Chronic viral hepatitis or HIV & 19 & 3.5 \\
\hline Chronic severe renal failure & 25 & 4.6 \\
\hline Hepatocellular insufficiency & 67 & 12.2 \\
\hline
\end{tabular}

Table 2. Estimation of adjusted odds ratio.

1842 prescriptions included, 1103 without missing data analysed.

The adjusted $O R$ seeks to explain the risk to receive the maximum $4 \mathrm{~g} /$ day acetaminophen dose.

\begin{tabular}{|c|c|}
\hline Hepatotoxic risk factor & $\begin{array}{c}\text { Adjusted Odds ratio } \\
{[95 \% \text { confidence interval] }}\end{array}$ \\
\hline Age $>75^{*}$ & $0.20[0.15-0.27]$ \\
\hline Weight $<50^{*}$ & $0.32[0.21-0.51]$ \\
\hline Malnutrition & $1.08[0.76-1.54]$ \\
\hline Chronic alcoholism & $0.67[0.42-1.06]$ \\
\hline Chronic viral infection & $0.94[0.44-2.04]$ \\
\hline Severe chronic kidney disease & $0.71[0.44-1.14]$ \\
\hline Hepatocellular insufficiency & $1.03[0.71-1.51]$ \\
\hline
\end{tabular}

*Significant $O R<1$ can be interpreted as a protective factor to receive a maximum dose (and thus associated with receiving less than $4 \mathrm{~g} /$ day). 